\title{
Politics, Sex, and Spirit: The Divided Self in Oscar Wilde's Salomé
}

\author{
Min Pun \\ Tribhuvan University, Pokhara, Nepal \\ Email:min.pun@gmail.com
}

\begin{abstract}
The paper aims to examine the self in Oscar Wilde's one-act play Salomé. In the play, there are three characters, namely, Herod, Salomé and Jokanaan who represent the three different worlds of expression. One represents the world of politics who is always in search of power, the second represents the world of sex who is in search of love and passion, and the third one represents the world of spirit who dedicates his life for God. These characters comprise of three different selves of Wilde and his writing, making his play as a fictionalized autobiographical work.

Keywords---poetic autobiography, politics, self, sex, spirituality.
\end{abstract}

\section{Introduction}

The critics who view Oscar Wilde's Salomé as an autobiographical play often mean that portions of major dramatics personae of his one-act play closely resemble with his life experiences. This terminology serves the right way of identifying a literary work that deeply helps form the beliefs and attitudes of the author.

Unless and until a writer's life experience include situations, actions, and convictions for independent evidence, everything one puts into the autobiography has a source somewhere in his life the definitive traits of this genre, then, lies somewhere in the literary and extra-literary life of the author (Zambrano et al., 2018; Wijaya, 2016).

Wilde's play reflects the everlasting problem of the author's self-conflict. He considers the self as a work of art. This conflicting aspect of his self shows that self-reflectiveness of the play. There are three different factors that work for his play as an autobiography: one, the autobiography is an individual matter; second, it is a symbolical expression of the self and the three, it fictionalizes the biographical information.

In short, Wilde's play as an autobiographical work not only deals with the individual that relates to his fragmented existences, it also reveals that his several selves come together and become one. This study thus moves from the biographical study of the author to the fictive mode of the play. Although many critics consider the play as an experimental work, this study has raised the autobiographical elements that are inherent in this play.

\section{Salomé as an Autobiographical Play}

The essential artistic element for the purpose, regarding Salomé as a true poetic autobiography, lies in its successful display of the self through fictive rather than biographical metaphors. Nevertheless, his position outside the action identifies him with the dramatis personae and the author is therefore publicly responsible for its moral issue. He felt this responsibility keenly, and whenever the symbolic action of the play required justifying himself, he identified with it in unmistakable terms as Stokes (1982), observes, "Wilde's discovery in the religious and dramatic ritual of a perverse means of dramatizing his own state" (p. 413). The identification he seeks with major dramatis personae i.e. Herod, Salomé and Jokanaan acknowledge the essential kinship between self-consciousness and the problematic self. The play also reveals the interaction of these two psychic activities, self-realization. Thus, the voice of selfconsciousness in Salomé foreshadows the dramatic interaction of the characters: "Throughout the play, the characters have looked at each other and been baffled by unyielding surfaces which, like mirrors, have only thrown back the reflection of the self. Herod is given the chance to 'look' at Salomé as she is in her inmost being" (Worth, 1983). 
"In writing a play or a book," Wilde (1946), himself says, "I am not at doing good or evil, but at trying that will have some quality of beauty" (The Picture, p. 7). This statement not only sums up his own theory of art but also indicates beauty that is necessary for a work of art, his prophetic insight is that he does not seek happiness but he is in search of pleasure, which inexorably precipitates tragic turn of events. It culminates his theory of life in tragedy and in the struggle between good and evil. Without a doubt, strenuously he upholds Salomé as a product of the gospel of 'Art of Arts Sake'. Regarding the aesthetic aspect of the play, he says, "humans might like to exercise our prowess with symbol systems, just because that's the kind of animal we are. I would view the poetic motive in that light" (Burke, 1966).

\section{Three Different Worlds of Wilde}

In his well-known one-act tragedy, Wilde portrays three distinctly different worlds of expression: political, sexual and spiritual. These worlds are represented by three main characters: Herod, the king, represents a political world of power and control; Salomé, the seductive maiden lures men by her physical spell and presence into a world of the sensuous delights, and Jokanaan, the messenger of God, speaks of the higher order that is inexpressible and unclear. One writes a drama simply for the satisfaction and writes in some subjects which, as Burke (1966) suggests:

Involve tensions or problems and since you can't make a drama without the use of some situation marked by conflict. Even though you hypothetically began through sheer love of dramatic, exercise, in the course of so exercising you tend to use as your subject matter such tension or problem as exercise yourself, or your potential audience, or mankind in general. Thereby you become variously involved in ways of "resolving" such tension or problem. And even though your drama is still motivated poetically by the love of the exercising for its own sake, it becomes so interwoven with the problem you symbolically resolve; people tend to see these problems as the motivating source of your activity. (p. 29)

In the play, Wilde's characters face tragedy. As the plot of the play progresses, they come across tragic moments to achieve the climax as different forces work together.

Herod Antipas, Tetrarch or Judaea, is a king, whose power rests on his political domination. In the play, he boasts how he drove the Young Syrian's father a king, from his kingdom and made a slave of his wife. He even imprisons the first husband of the queen Herodias who was his own elder brother. He imprisons his brother for twelve years who is strangled at the end. Then, Herod admires, the ultimate model of regal power by force. Caesar is a conqueror of many lands and can execute whomsoever he wishes including Herod's fierce foe, the king of Cappadocia. As a result, in Herod's mind, Caesar is wonderful and he can do everything he likes:

SECOND SOLDIER: Yes, he a somber look.

HEROD: Wherefore should not be happy? Caesar, who is lord of the world, who is lord of all things, loves me well. He has just sent me the most precious gifts. Also, he has promised me to summon to Rome the king of Cappadocia, who is my enemy. It may be that at Rome he will crucify him, for he is able to do all the things that he wishes. Verily, Caesar is lord. Thus you see I have a right to be happy. Indeed, I am happy. I have never been so happy. There is nothing in the world that can mar my happiness. (Wilde, 1992)

But, of course, Herod's means of expression of power by force is inferior to either Salomé or Jokannan's means. For instance, Salomé's horrific demand for Jokanaan's head shatters Herod's political power. In other words, Salomé insists on her selfish fulfillment that compels him to say: "Your beauty has grievously troubled me, and I have looked at you too much. But I will look at you no more. Neither at things nor at people should one look. Only one mirror should one look, for mirrors do but show as masks" (Wilde, 1992). It is to be recalled that Herod calls himself as the slave of his word.

Herod, arising from and empowered by the conflicts between passionate Salomé and moral Jokanaan with whom Wilde is also necessarily at odds only for the art's sake, seek his absolute self that connects them probing everything with a cautious touch like a miner searching for gold. Thus, the ambiguous role played by fully dramatized character Herod. One being not only a spectator but also a major dramatis personae in the mental stage of Wilde is both responsible for and deeply affected by the events of the play. In this connection, Katherine Worth (1983), observes "He is the first of Wilde's characters to be self- conscious in a thoroughly convincing and interesting way, the only in the play who turns on himself the 'look' they are fated to turn on each other" (p. 62). However, Herod is a type of an inquisitive spirit that Wilde detected in his artistic method and personifies in the autobiographical, a voyeur who takes delight entirely through the acts of other people (Deori, 2015; Putrayasa, 2017). 
Salomé, daughter of Herodias, possesses power and means of expression through her physical body. She gains an integration of the self only by nourishing and satisfying the will of the ego to dominate the world. She seduces men by her beauty and manipulates and controls them to do whatsoever she wishes. For instance, by means of the dance, which is the dance of the seven veils, she tantalizes Herod and brings him under her sway. Salomé exploits the irrational as a means to power. Now, she can demand anything she wishes from Herod:

SALOMÉ (rising): The head of Jokanaan.

HERODIAS: Ah that is well said, my daughter.

HEROD: No, no

HERODIAS: That is well said, my daughter.

HEROD: No, no Salomé. You do not ask me that. Do not listen to tour mother's voice. She is ever giving you evil counsel. Do not heed her.

SALOMÉ: I do not heed my mother. It is for mine own pleasure that I ask the head of Jokanaan in a silver charger. You have sworn, Herod. Forget not that you have sworn an oath. (Wilde, 1992)

Herod is, therefore, forced to appease Salomé's insatiable desires with the only thing that he does not want to give. Appropriately just as Herod wants Salomé, Salomé demands that person whom she cannot have, control and understand: she derives Jokanaan, the incarnation of spirituality only after he is separated from his life: "Ah, Jokanaan, Jokanaan, those were the only man that I have loved [...] saw thee, Jokanaan, and loved thee" (Wilde, 1992). She rhapsodizes voluptuously. As Herod goes out, Salomé fulfills her desire when her voice continues, "I have kissed thy mouth. There was a bitter taste on thy lips. Was it a taste of blood?' (Wilde, 1992).

Salomé is a portrait of women by a male author. It is appropriate to say that it is merely a projection of certain traits of Wilde's intuitive or "poetic" nature. And in the play, Salomé offers self-revelation with which Wilde is fundamentally concerned. Through the set of symbols, Salomé's character can be found scattered throughout the play, which records Wilde's identification with the deductive but tainted woman who came gradually to represent Wilde's artistic life. So Salomé embodies the artistic impulse of Wilde that he locates her in his heart and calls the imagination which has no power to control them.

Jokanaan, the prophet, possesses power in the spiritual world. His language is often biblical but he is harsh. He finds it difficult to admit to himself as Wilde often did the responsibility for his own offspring both human and literary. And even he is as obsessive on his denunciations as Herod and Salomé are in their passion. Jokanaan is capable of raising people from the dead, fuelling the future, and speaking in tongues or the truth of God. Salomé herself is curious to know Jokanaan's origin. Similarly, Herod and Herodias quarrel over the designation of "he" in Jokanaan's speech as "He shall be eaten of worms" (Wilde, 1992). His great power, in fact, frightens Herod when Herod claims unconvincingly to his wife:

HERODIAS: I do not believe in prophets. Can a man tell what will come to pass? No man knows it. Moreover, he is for even insulting me. But I think you are afraid of him [...] know well that you are afraid of him.

HEROD: I am not afraid of him. I am afraid of no man. (Wilde, 1992)

Jokanaan's world is completely alien to Herod, and whatsoever he does he cannot face Jokanaan or his world, and to escape from them. The dead body, for instance, completely terrifies Herod; the dead are part of another world that he cannot handle, and he orders Jokanaan not to tamper with this other world that he wishes to avoid.

\section{The Conflict of the Self}

Herod does not deny that Jokannan's world exists, and he is capable of recognizing Jokanaan's world. As in most tragic plays, there is a continual repetition of the fate motif. Not only does he know Jokanaan is a prophet, but he hears "the beating of giant wings" (Wilde, 1992). The wings of death, above the palace and sees "the blood, which is an evil omen" (Wilde, 1992). This is a device used by the dramatist in order to warn the audience that the outcome is to be tragic. However, Herod does not wish such a world to intrude on his own.

Herod, therefore, symbolically imprisons Jokanaan and hopefully Jokanaan's world as well, and he calls for more feasting - more wine, more dancing and anything else that will preoccupy him through these uncomfortable moments that speak of another supernatural world. In this connection, Epifanio San Juan (1967), argues, "Jokannan's declarations demand a content explanation for their underlying since the world of the play does not possess any authoritative code of meanings" (p. 124). Then, when this other world becomes too powerfully revealing for him such as Jokanaan's head on a silver platter, he flees. No amount of revelry can allow him to overlook the horror that this other world shall bring. 
Salomé, on the other hand, is incapable of understanding Jokanaan's world. She can only see the physical attributes of herself and of Jokanaan. She describes beautifully and eloquently Jokanaan as a 'column of ivory', his hair as 'a cluster of grapes' and his mouth as 'red as pomegranate flower', but she fails to mention anything about his character, personality, attributes, gifts, or drawbacks. She directly reveals her true intentions when she says "Jokanaan, I am amorous of thy body [...] There is nothing in the world as white as thy body. Let me touch thy body" (Wilde, 1992). Jokanaan is only a physical object which she desires. She is trapped within her own physical world of the senses, as she says later,

[...] Well hast saw thy God, Jolanaan, but me, me, thou didst never see. If thou hadst has seen me thou wouldst have loved me. I, I saw thee, Jokanaan, I loved thee, Oh, how I loved thee yet, Jokanaan, I loved thee only [...] I am athirst for thy beauty; I am hungry for thy body, and neither wine nor fruits can appease my desire. What shall I do now, Jokanaan? (Wilde, 1992)

Jokanaan's spiritual eye, however, is incapable of seeing or understanding Salomé, and the world in which she lives. This preaches a climax when at the dramatic end she is making love with Jokanaan's severed head - kissing, caressing and idolizing it. This characterizes the aesthetics of Wilde. In turn, the aesthetic experience has been described as resulting from "the viewing of certain perceptual patterns under a special attitude of mind" (Shipley, 1953). This special attitude, the aesthetic attitude, for Wilde, is the one which contemplates the life and reality of the play to the exclusion of the life and reality out of which it springs. According to Katherine Worth (1983), the catharsis works in the play as the poison is out, and Salomé moves into saddening music as she is attracted towards Jokannan; white, red and black remain as the sign of beauty as she says: "' thy body was a garden full of doves and of silver lilies $[\ldots]$ there was nothing in the world so black as thy hair $[\ldots]$ In the whole world there was nothing so red as thy mouth.' That is her elegy for him" (p. 69). Her obsession with the physical has driven her to a kind of psychopathic necrophilia. She is trapped.

Jokanaan cannot 'see' Salomé's physical world, nor can he enjoy Herod's festive occasion. For him, the real world is one of the spirits, the supernatural and of God. And this world is incommunicable through objects or words of logic, but it is expressed through a kind of bardic voice. When Jokanaan speaks, no one seems to understand him, especially Herodias. He is seen as a kind of madman by the other; he speaks in a logic that is unfamiliar, and his voice has the tone of an oracle, a seer, a seer not of the physical world. Herodias beckons for him to stop speaking:

THE VOICE OF JOKANAAN: Who is this who cometh from Edom, who is this who couth from Bozra, whose raiment is dyed with purple, who shined in the beauty of his garments, who walked mighty in his greatness? Wherefore is thy raiment stained with scarlet?

HERODIAS: Let us go within. The voice of that man maddens me I will not have my daughter dance while he is continually crying out. I will not have her dance while you look at her in this fashion. In a world, I will not have her dance. (Wilde, 1992)

Jokanaan utters a world order that is altogether strange and inconceivable to her - the mystical and supernatural. Thus, the absence of order in the outer world is compensated by the triumphant discovery of order in the works of literature and defining this order purely in terms of form. Wilde's aesthetics here is necessitated by a search for purely formal qualities in a literary work, with the breakdown of the tradition and belief.

Woodberry (1951), suggests that "the essence of the work, its living power for us, is not what the artist put in it, but what we draw from it, its world-value is not what it was to the artist, but what it is to the world" (pp. 98-99). This is now Wilde's play that is entertainment or the portrayal of disorder that stirs intriguing revelation of the conflicts of three distinct worlds or "selves" and their modes of expression and communication. In addition, each of these three figures typifies one of the conflicting ideas Wilde held about the purposes of art in general and about himself as an artist in particular. It deals with a work where a beautiful object lies and ignores the issues of meaning and morality. The only relevant meaning is the affairs - money, politics, and power that is usually associated with men and portrayed by the king Herod. In the middle, there is the world delight - the sensuous, instinct, sex and the body that is affiliated with woman and characterized by Salomé, and then there is the world of the sublime - spirits, the unseen, the mystical, and the supernatural that is attached to God and acted for by Jokanaan. All three have a crucial place in the tension of the play. These three worlds of reality or order are in constant struggle with the other either to reject the world(s) below them or to gain something from the world directly above them. But the remark of Juan (1967), is that "while there exists between them an unrelenting tension, there is also a strange force of attraction that them together, as though complementing pairs, to constitute a whole" (p. 127). 
At the lowest level, Herod wishes something from Salomé, from the sensuous world of delight; he asks her to dance for him. Secondly, Salomé wants something spiritual to balance her limited, physical world; she desires the incarnation of that spirituality, Jokanaan only desires the world of God and all gain what they want. For instance, Herod sees Salomé dance; Salomé receives Jokanaan, and Jokanaan meets the world of God. There is a tragedy. Does Wilde wish to suggest that these worlds are mutually exclusive? And when they meet, will disaster- and chaos always result? Throughout the play, the characters tend to be isolated from one another, being superficially connected to the main episodes; Herod's marriage feast and Salomé's dance. This sense of isolation infuses strangeness into the individual voices we hear. In other words, the worlds may never be able to reconcile with one another, but all three will be in a constant struggle with one another. Knight (1969), in this connection, remarks:

In Salomé decadent and bejeweled paganism in a sumptuous atmosphere of beauty and blood-lust asserts itself statically and repetitively against the equally repetitive denunciation of Jokanaan, or John the Baptist, whom Salomé desires. Always in Wilde, the two worlds want to meet. Here they coexist in unhealthy opposition: The atmosphere is like pressure before thunder. (pp. 143-144)

The politician shall never agree with the theologian; the prostitute will always be rejected by the priest, and the prostitute will always be exploited by the politicians. No balance, no communication, no giving, and taking shall ever be attainable in the world of Salomé stage.

Here, the view of Katherine Worth (1983), aptly supports this consideration that a literary work had its own special mode of existence, its own frame of reference, different from that of actual life is a fundamental truth of aesthetics, as she writes - "What it does show is that was looking for a new way of expressing the idea demonstrated tragically in Salomé: An extreme of passion is drawn to its own opposite and the two can never be harmonized, only clash or reverse themselves" (p. 184). While Herod, Salomé, and Jokanaan represent the three conflicting elements into which Wilde felt himself to be divided, Salomé's dance represents the imaginative creation that causes this conflict. It is a primary object of the vexing problem for Herod and a possible connection between Jokanaan and Salomé:

SALOMÉ: Give me the head of Jokanaan.

HEROD (sinking back in his seat): Let her be given what she asks of a truth she is her mother's child (The FIRST SOLDIER approaches, HERODIAS draws from the hand of the TETRARCH the ring of death and gives it to the SOLDIER who straightway bears it to the EXECUTIONER. The EXECUTIONER looks scared) ...

HERODIAS: My daughter has done well. (Wilde, 1992)

In this respect, Salomé's desire for the head of Jokanaan, a desire shared in some way by Herodias, simultaneously represents and furthers the aim of the symbolic action, of which she is at once the cause and the living emblem. As Katherine Worth (1983), suggests, Salomé's dance is the dance of the seven veils and is "an enigmatic event. How would it have been done by Sarah Bernhardt at the Palace Theatre, who can tell? Voluptuous in fin de siècle style, presumably" (p. 64). The aim of symbolic action does not reveal something known but rather to find out the uncontrollable offspring of Wilde's private self in the secret spring of Salomé's dance. For the truth is both "Symbolically expressive and morally comprehensible, creative, and intelligible, hidden in the secret heart and revealed to the world" (Spengemann, 1980).

The characters act out the relation among them which recapitulate Wilde's reflection of the heart in a uniquely complex form. While this mental stage tends to posit the exterior world only to withdraw immediately in the secret heart unaffected by the action, Salomé includes the public realm in the symbol by making it mirror-image of the heart. The belief that the portrayal of Salomé's dance is representative, which brings himself to be so true, symbolic by which the worst in him is inferred and redeemed by an understanding public. The resulting figure is the dance which represents the analogous moral condition of individual and public existence, which is for Spengemann, collectively secure but secretly troubled, the great of humanity is, in fact, a microcosm of the individual heart, with its sunny portal and dark interior. Outside the entire design, the heavenly goal of Jokanaan's spiritual aspiration where Salomé hopes her sinful love is finally redeemed and the universal counterpart of the absolute truth at the center of the individual heart.

\section{Poetic Autobiography of Wilde}

The poetic autobiography becomes neither a historical nor a philosophical analysis of a life lived elsewhere, but a series of actions performed in the composition of Salomé or a record of these actions; in short, a book about its own 
origins, processes, and consequences. The dance stands for a word that is also a deed, which is mentioned in the letter of Coleridge written to William Godwin:

I wish you to write a book on the power of words [...] is thinking impossible without arbitrary signs? And how far is the word "arbitrary" a misnomer? Are not words, etc., parts and germinations of the plant? And what is the law of their growth? In something of this sort, I would endeavor to destroy the old antithesis of Words and Things; elevating, as it were, Words into Thing and living things too. (Spengemann, 1980)

Salomé comprises verbal deeds which simultaneously enact, record, and interpret a fictive confrontation among the several aspects of himself that Wilde felt to be in conflict as he places upon his mental stage, as actors in the drama. In regard to the dance of the seven veils, Katherine Worth (1983), suggests that Wilde has often used this particular ceiling and unveiling imagery in his writings, which is associated with his spiritual enlightenment in which "unveiling was an appropriate image for the activity which Wilde regarded as the artist's primary duty: selfexpression and self-revelation. In performing the dance of the seven veils, Salomé is then perhaps offering not just a view of the naked body but of the soul or innermost beings" (Wimsatt \& Brooks, 1964).

The dance enacted by the characters upon Wilde's mental stage is determined by the situation in which these characters find themselves divided. Throughout the play, Juan (1967), observes, "The characters tend to be isolated from one another, being superficially connected to the main episode: Herod's marriage feast. This sense of isolation infuses stringencies into the individual voices we hear, reinforcing the fact that the context of their talk is out vaguely implied" (p. 118). As the play develops each character is in conflict with each other as a direct result of Salomé's physical attraction:

HERODIAS: You must not look at her! You are always looking at her!

HEROD: The moon has a strange look to-night. Has she not a strange look? She is like a mad woman who is seeking everywhere for lovers. She is naked, too. She is quite naked. The clouds are seeking to clothe her nakedness, but she will not let them. She shows herself naked in the sky. She deals through the clouds like a drunken woman [...] I am sure she is looking for lovers. Does she not really like a drunken woman? She is like a mad woman, is she not? (Wilde, 1992)

Given this situation and the autobiographical problem it represents, the action tries to reconcile all of these characters and bring the estranged parties together on a common ground

As their mutual estrangement arises from the appearance as of the marriage feast and Salomé's last dance, their reconciliation depends upon their coming to some agreement about the meaning of such symbol. The agreement depends, in turn, upon what Katherine Worth (1983), calls "a significantly imaginative dance" (p. 67). In some sort into something, all selves can accept on the same terms. And since the symbol derives its meaning from the world in which it has come, its reevaluation requires a significant change in that world, that is, both in the moral structure of the symbol and in the form of writing itself.

The symbolic action that issues from the situation is best described as a movement by Salomé and Jokanaan between the poles of private and public reality. As these characters are represented in the play, in search of the true place where her individual, passionate energies and his public, moral structure can be united into a complete being. Customarily, the play begins by withdrawing from the public world to seek the truth within Salomé open in the exterior reality, with the identification of the symbol that Salomé has so artfully embroidered in her dance. Indeed, there is almost complete agreement on this matter. Herod ultimately accepts the idea that Salomé demands the head of Jokanaan as a sign of evil: "I am sure that some misfortune will happen" (Wilde, 1992). And he, therefore, cannot bring himself to participate in Salomé's obsession anymore. Herod refuses to acknowledge Salomé publicly and shares the public obligation or affectionate ties to Jokanaan. On the contrary, Salomé obeys her own heart and agrees to take Herod's identity a threat.

At first, then, the entire characters stand together on the public ground of their inability to see each other by any virtue that permits them to associate themselves with it. Salomé shares the general opinion that her dance signifies only evil. However, her defiant embroidery of it expresses, in the heart's native language, something her reason cannot admit: that her fallen state is the truth, not a deviation from it. Any assuagement of her condition depends upon her unchanged belief to the hard truth symbolizes by her wanting to possess the body of Jokanaan. Juan (1983), says that she is apprehensive because she knows that "the satisfaction of her aortic drives is beyond what the brief pleasures of earth can afford; her desire exceeds the finitude of the circumstances in which she is caught, as in a painful snare" (pp. 121-122). In any case, she fulfills her desire, which she cannot admit even to herself, to be near Jokanaan. 
Apparently, in Salomé, Wilde has revealed the firm ground upon which the extraordinary private imagination and ordinary public mind can write in the harmony of complete being through the symbols of own action. It passes swept away by the way tide of symbolic action that has brought them into being, as Stokes (1982), considers the symbolist approach aspired to:

An overall impersonality that would rid the drama of moral bias. If Salomé represents the destructive impulses of the Decadent artist, the mode of the play in which she appears aspires to a symbolic wholeness that will appease the artist hellish solipsism. (p. 413)

If Salomé is to have disclosed the source of that light which illuminated both the deepest private heart and the exterior public world, Wilde's celebrated play points beyond itself to the unconditioned ground of his fragmented existence and reveals to be the only place where his several selves can come together and be one.

A keynote of the action is the simplicity that is expressed through Salomé's question about Jokanaan: "is he an old man, the prophet?" (Wilde, 1992). Such a dramatic progression of climaxes is seen throughout the play, each leading to another. In this connection, Juan (1983), states - "Such a formal design moves by psychological, not logical profession. Its energy animates a pattern of utterances in which conscious and unconscious motivation heightens and clarifies one another" (p. 118). In this way, the audiences see Salomé's love for the prophet, Herod's entrance and demand for Salomé to dance and then another moment of suspense. In short, all these rapid climaxes signify dramatic progression. These events also parallel Wilde's personal life in many respects.

Herod's final words sound frustrating: "She is monstrous, thy daughter, she is altogether monstrous. In truth what she has done is a great crime. I am sure that it was a crime against an unknown God" (Wilde, 1992). It is impossible not to hear in them an undertone of relief. The play has shaped itself against Wilde's insertions and the characters have acted otherwise rather than the thought. Wilde has struggled in vain to avert the catastrophe precipitated by these unforeseen actions, admonishing Jokanaan who does not "wish to look at thee" (Wilde, 1992), rather than bring infamy on his sacred profession. Nevertheless, this catastrophic revelation seems to fulfill Herod's design as much as to frustrate them.

The action of the play has been motivated all along by a lurid intermixture of love and hate, those apparently opposite feelings which become the same thing at the bottom. Only the action can reconcile the conflicting demands of privacy and publicity, hiding what Salomé reveals, when she says: "I will dance for you, Tetrarch" (Wilde, 1992). Because Salomé reveals to Wilde an absolute ground behind his public and private selves, but rather proves itself to be the only place where the actual and the imaginary can imbue itself with the nature of the other. The self-division that has been poetically healed in the autobiography persisted in by the autobiographer. Wilde has spent the rest of his life in search of an immortal self that he could neither fully believe in any longer nor relinquish to the realm of art what Wilde (1962), expresses in his letter as "a curious mixture of ardor and of indifferent. I myself would sacrifice everything for a new experience, and I know there is no such thing as a new experience at all" (The Letters, p. 559).

This search is recorded in Salomé: the actions, forms, characters, and emblems reflect the self-conflict which is the enduring problem for Wilde. He comes to the conclusion that reveals the hopelessness of his ever evading self shadowed forth when he makes himself the personages of Salomé. It confirms what the play has said, "no man hath seen God since the prophet Elias" (Wilde, 1992): that he has no self beyond the one created in his autobiography. At the end of the fruitless quest, when he would no longer find his way, he let one of his characters express his feeling of selflessness:

Ah! There speaks the incestuous wife! Come! I will not stay here come I tell thee. Surely some terrible thing will befall. Manasseth, Issachar, Ozias, put out the torches. I will not look at things; I will not suffer things to look at me. Put out the torches! Hide the moon! Hide the stars! Let us hide in our Palace, Herodias. I began to be afraid. (Wilde, 1992)

Wilde's attachment to the play and his consequent inability ever to find it again made him unwilling to continue his search for self-knowledge that has directed his creative life. Although Wilde himself only half knows it, he finds the true being, his true society and his immortal self in Salomé.

\section{Conclusion}

Wilde's Salomé depicts the divided selves of the author that there is no any sign of unity rather it provides a way to his spiritual growth. Although many critics have considered his work as an account of his life, it shows his personality and artistic aspect of his work. 
The play as his gift of writing, thus, reflects the Wilde's poetic genius, which is called as a poetic autobiography. For instance, through his characters like Herod, Salomé, and Jokanaan, he has presented the conflicting aspects of his life by means of his artistic genius. When these characters come together, the conflict begins to grow within the world of a person like Wilde. They again represent different selves of the author that exist in different worlds of expression.

In conclusion, the self plays a vital role in Wilde's one-act play, showing the inherent conflict in a human being. However, the conflict within him is reconciled only when there is poetic action is at play. It means that the artists spend their life in drawing the portrait of their own selves into the works of art.

\section{References}

Burke, K. (1966). Language as symbolic action: Essays on life, literature, and method. Univ of California Press.

Deori, B. (2015). Identity formation and political assertion among the deoris. International Research Journal of Management, IT and Social Sciences, 2(3), 5-10.

Ellmann, R. (1969). Oscar Wilde; a collection of critical essays (Vol. 87). Prentice-Hall.

Epifanio Jr, S. J. (1967). The Art of Oscar Wilde. Princeton: Princeton UP.

Juan, E. S. (1967). Orientations of Max Weber's Concept of Charisma. Centennial Review, 270-285.

Putrayasa, I. B. (2017). The semantic study of languages politics. International Journal of Linguistics, Literature and Culture, 3(2), 7-13.

Shipley, J. T. (1970). Dictionary of World Literary Terms, Forms, Technique, Criticism. Writer.

Spengemann, W. C., \& Spengemann, W. C. (1980). The forms of autobiography: Episodes in the history of a literary genre. New Haven: Yale University Press.

Stokes III, J. B. (1982). Ion transport by the cortical and outer medullary collecting tubule. Kidney international, 22(5), 473-484. https://doi.org/10.1038/ki.1982.200

Wijaya, N. (2016). Questioning the credibility of foreign researchers' findings in respect of identity politics of Balinese people. International Research Journal of Management, IT and Social Sciences, 3(5), 8-15.

Wilde, O. (1962). The Letters of Oscar Wilde. Rupert Hart-Davis, Limited.

Wilde, O., Jackson, R., Small, I., \& Bristow, J. (2000). The Complete Works of Oscar Wilde: The picture of Dorian Gray: the 1890 and 1891 texts (Vol. 3). Oxford University Press on Demand.

Wilde, S. A. (1946). Forests Soils and Forests Growth (Vol. 62, No. 4, p. 341). LWW.

Wimsatt, W. K., Brooks, C., \& Adams, R. M. (1957). Literary criticism, a short history. The Hudson Review, 10(3), 477-480.

Worth, K. (1983). Farce and Michael Frayn. Modern Drama, 26(1), 47-53.

Zambrano, M. L. V., Barreto, M. D. L. A. C., \& Chica, T. K. M. (2018). Intervention of social work in political participation of women in forming process of neighborhood councils of canton Portoviejo. International Journal of Social Sciences and Humanities, 2(1), 134-146. https://doi.org/10.29332/ijssh.v2n1.104 